\title{
Lead sorption and leaching from an Inceptisol sample amended with sugarcane vinasse
}

\author{
Bruno Teixeira Ribeiro ${ }^{1 *}$; José Maria de Lima²; Luiz Roberto Guimarães Guilherme²; \\ Luiz Gustavo Fernandes Julião ${ }^{3}$ \\ ${ }^{1}$ IF SULDEMINAS - Campus Machado/CGPP, Rod. Machado - Paraguaçú, km 3 - Campus Machado - \\ 37750-000 - Machado, MG - Brasil. \\ ${ }^{2} U F L A$ - Depto. de Ciência do Solo, C.P. 3037 - 37200-000 - Lavras, MG - Brasil. \\ ${ }^{3}$ UNICAMP/Faculdade de Engenharia Agrícola, C.P. 6011 - 13083-875 - Campinas, SP - Brasil. \\ *Corresponding author <ribeiro.bt@gmail.com>
}

\begin{abstract}
Vinasse is produced at high amounts by the ethanol and sugarcane spirits industries. Although the effects of vinasse on soil attributes are well elucidated, little is known about its effects on sorption and leaching of lead $(\mathrm{Pb})$ from soils. This work evaluated the $\mathrm{Pb}$ sorption and leaching from disturbed topsoil samples $(0-20 \mathrm{~cm})$ of an Inceptisol, under the influence of sugarcane vinasse. $\mathrm{Pb}$ sorption was evaluated by batch sorption method, using air-dried samples $(<2 \mathrm{~mm})$ treated with pure $(100 \%)$, and diluted $(20 \%$, and $50 \%$ ) vinasse. The amended soil samples were further reacted with $0.05 ; 0.10 ; 0.25 ; 0.50$, and $0.75 \mathrm{mmol} \mathrm{L}^{-1}$ of $\mathrm{Pb}$. To measure the $\mathrm{Pb}$ leached, soil columns were packed in PVC tubes, $12-\mathrm{cm}$ long with $4-\mathrm{cm}$ internal diameter filled with $200 \mathrm{~g}$ of treated soil. The vinasse doses applied over the columns corresponded to 0 (control), 150 and $300 \mathrm{~m}^{3} \mathrm{ha}^{-1}$. Seven days later, $5 \mathrm{~mL}$ of a Pb solution $\left(100 \mathrm{mmol} \mathrm{L}^{-1}\right)$ was applied on the columns; they were successively leached and $\mathrm{Pb}$ was measured in the leachates. The vinasse increased the maximum sorption capacity and binding energy of $\mathrm{Pb}$ with the soil when at equilibrium conditions. However, at non-equilibrium conditions, the vinasse enhanced the $\mathrm{Pb}$ leaching. From these results, it is advised that special attention must be given to $\mathrm{Pb}$ contaminated areas where vinasse is applied.

Key words: sugarcane cultivation, organometallic complexes, organic waste, $\mathrm{Pb}$ mobility
\end{abstract}

\section{Sorção e lixiviação de chumbo em amostra de um Cambissolo tratado com vinhaça de cana-de-açúcar}

\begin{abstract}
RESUMO: A vinhaça é produzida em grandes quantidades pela indústria de etanol e de aguardente (cachaça). Embora os efeitos da vinhaça nos atributos do solo sejam bem conhecidos, pouco se sabe sobre eles no comportamento sortivo de chumbo $(\mathrm{Pb})$. Avaliaram-se a sorção e a lixiviação de $\mathrm{Pb}$ em amostras da camada superficial $(0-20 \mathrm{~cm})$ de um Cambissolo Háplico Tb Distrófico típico (CXbd) sob influência da vinhaça. Para o ensaio de sorção, as amostras foram peneiradas em malha de $2 \mathrm{~mm}$, tratadas com vinhaça diluída $20 \%$ e $50 \%$ e ao natural (100\%), empregando água destilada nas amostras controle. Em seguida, soluções com 0,05; 0,10; 0,25; 0,50 e 0,75 $\mathrm{mmol} \mathrm{L}^{-1}$ de $\mathrm{Pb}$ foram adicionadas às amostras de solo. Para o ensaio de lixiviação, foram preparadas colunas de solo em tubos de PVC de $12 \mathrm{~cm}$ de altura e $4 \mathrm{~cm}$ de diâmetro interno, contendo $200 \mathrm{~g}$ de solo. As doses de vinhaça aplicadas sobre as colunas foram correspondentes a 150 e $300 \mathrm{~m}^{3} \mathrm{ha}^{-1}$. As colunas foram mantidas incubadas com vinhaça por sete dias. Após esse período, foram aplicados sobre cada coluna 5 $\mathrm{mL}$ de uma solução de concentração $100 \mathrm{mmol} \mathrm{L}^{-1}$ de $\mathrm{Pb}$ e, posteriormente, realizadas sucessivas lixiviações, coletando-se o percolado para determinação do teor de $\mathrm{Pb}$. A vinhaça aumentou a capacidade máxima de adsorção de $\mathrm{Pb}$ e sua energia de ligação com o solo em condições de equilíbrio (ensaio de sorção), mas em condições de não equilíbrio (ensaio de lixiviação em colunas), a vinhaça aumentou a lixiviação de $\mathrm{Pb}$. Com base nesses resultados, atenção especial deve ser dada a áreas que estejam recebendo vinhaça ao longo dos anos e que estejam ocasionalmente sujeitas à contaminação por $\mathrm{Pb}$.

Palavras-chave: cana-de-açúcar, complexos organo-metálicos, resíduo orgânico, mobilidade de $\mathrm{Pb}$
\end{abstract}

\section{Introduction}

Vinasse is produced at the rate of $12-13 \mathrm{~L}$ per liter of ethanol or sugar cane spirits (Freire and Cortez, 2000; Martinelli and Filloso, 2008). About 27 billion liters of ethanol (IBGE, 2009) and 350 billion liters of vinasse are produced yearly in Brazil. It consists mainly of water, organic matter (organic acids and sugars) and cations such as $\mathrm{K}, \mathrm{Ca}$, and $\mathrm{Mg}$ (Freire and Cortez, 2000; Doelsch et al., 2009).
In the past, vinasse was dumped into watercourses, causing great environmental impacts (Günkel et al., 2007); nowadays, it is being applied to soil, mainly in sugarcane crops, as liquid industrial waste fertilizer (Freire and Cortez, 2000). Some of the effects of the vinasse on physical, chemical and biological attributes of soil were studied by Camargo et al. (1983), Leal et al. (1983), Neves et al. (1983), Mattiazzo and Glória (1987), Sengik et al. (1988), Franco et al. (2008) and Doelsch et al. (2009). However, little is known about its effect on

Sci. Agric. (Piracicaba, Braz.), v.67, n.4, p.441-447, July/August 2010 
the sorption of heavy metals, such as Lead $(\mathrm{Pb})$, especially in Brazil.

$\mathrm{Pb}$ can be present in soil due to weathering processes, mining and smelting activities (Kabata-Pendias and Pendias, 2000; Sharma and Dubey, 2005), and also by the agricultural use of phosphate fertilizers, sewage sludge or biosolids (Silveira et al., 2003; Borges and Coutinho, 2004; Oliveira et al., 2005; Campos et al., 2005; Silva et al., 2006; Camilotti et al., 2007; Torri and Lavado, 2008; Galdos et al., 2009).

The soil organic matter is the most important attribute that account for $\mathrm{Pb}$ sorption in soils (Sipos et al., 2005; Vega et al., 2007). The organic matter-Pb complexes can be soluble and leach in the soil, contaminating groundwater (Jalali and Khanboluki, 2007) whereas the mineral solid phase may account for its immobilization (Madrid and Díaz-Barrientos, 1998).

We here hypothesize that the presence of vinasse in soil, especially due to their soluble organic compounds, will increase leaching of $\mathrm{Pb}$. The main objective was to evaluate the vinasse effect both on $\mathrm{Pb}$ sorption and $\mathrm{Pb}$ leaching in a topsoil sample from an Inceptisol.

\section{Material and Methods}

\section{Sample preparation and incubation with vinasse for $\mathrm{Pb}$ batch sorption experiment}

Topsoil samples (0-0.2 m) of a Typic Dystrustepts (Cambissolo Háplico distrófico, according to Brazilian System of Soil Classification), located at Lavras, Minas Gerais State, Brazil, were used for this study. Selected physical and mineralogical attributes, determined according to Embrapa (1997), are in Table 1.

The samples were air-dried for 72 hours and sieved to $<2 \mathrm{~mm}$. Then, $50 \mathrm{~g}$ were placed in stainless-steel micro columns (6.0 cm high and $3.5 \mathrm{~cm}$ internal diameter), whose base was perforated. Then, they were saturated by capillarity action for $48 \mathrm{~h}$ with distilled water (control - T0), diluted vinasse at 20\% (T1), 50\% (T2) with distilled water and natural vinasse (T3). After saturation, the columns were incubated for seven days, and air dried. Then, soil samples were removed from the columns, air-dried for $72 \mathrm{~h}$ and sieved in a $2-\mathrm{mm}$ mesh for chemical characterization, according to Embrapa (1997) (Table 2).
The vinasse (from sugar cane spirits production) presented acidic character $(\mathrm{pH}=3.5)$, potassium $\left(2.5 \mathrm{~g} \mathrm{~L}^{-1}\right)$, solid residue $\left(9.6 \mathrm{~g} \mathrm{~L}^{-1}\right)$ and total organic carbon $(9.0 \mathrm{~g}$ $\left.\mathrm{L}^{-1}\right)$. Potassium content was determined directly from the natural vinasse via a flame photometer. Total organic carbon was determined after the digestion of $0.5 \mathrm{~mL}$ of natural vinasse with potassium dichromate and titration with ammoniacal ferrous sulfate. $\mathrm{Pb}$ content was determined in an Atomic Absorption Spectrophotometer, with an air/acetylene flame (detection limit around 0.040 $\mathrm{mg} \mathrm{L}^{-1}$ ), and not detected in the vinasse.

For the $\mathrm{Pb}$ sorption, $0.25 \mathrm{~g}$ of vinasse pre-treated soil was placed in $30-\mathrm{mL}$ bottles in suspension with $25 \mathrm{~mL}$ of $\mathrm{Pb}$ solution, at the concentrations of $0 ; 0.05 ; 0.10 ; 0.25$; 0.50 and $0.75 \mathrm{mmol} \mathrm{L}^{-1}$. They were prepared from

Table 1 - Selected physical and mineralogical attributes of the Inceptisol.

\begin{tabular}{|c|c|}
\hline Attribute & Value \\
\hline Clay $\left(\mathrm{g} \mathrm{kg}^{-1}\right)$ & 405 \\
\hline Silt $\left(\mathrm{g} \mathrm{kg}^{-1}\right)$ & 114 \\
\hline Sand $\left(\mathrm{g} \mathrm{kg}^{-1}\right)$ & 481 \\
\hline $\mathrm{D}_{\mathrm{p}}\left(\mathrm{g} \mathrm{cm}^{-3}\right)$ & 2.42 \\
\hline $\mathrm{SiO}_{2}^{*}\left(\mathrm{~g} \mathrm{~kg}^{-1}\right)$ & 149 \\
\hline $\mathrm{Al}_{2} \mathrm{O}_{3}^{* *}\left(\mathrm{~g} \mathrm{~kg}^{-1}\right)$ & 141 \\
\hline $\mathrm{P}_{2} \mathrm{O}_{5} * *\left(\mathrm{~g} \mathrm{~kg}^{-1}\right)$ & 0.17 \\
\hline $\mathrm{TiO}_{2}^{* *}\left(\mathrm{~g} \mathrm{~kg}^{-1}\right)$ & 7.4 \\
\hline $\mathrm{Fe}_{2} \mathrm{O}_{3} * *\left(\mathrm{~g} \mathrm{~kg}^{-1}\right)$ & 24 \\
\hline $\mathrm{Ki}$ & 1.8 \\
\hline $\mathrm{Kr}$ & 1.6 \\
\hline $\mathrm{Kt}\left(\mathrm{g} \mathrm{kg}^{-1}\right)$ & 228 \\
\hline $\mathrm{Gb}\left(\mathrm{g} \mathrm{kg}^{-1}\right)$ & 23 \\
\hline $\mathrm{Kt} /(\mathrm{Kt}+\mathrm{Gb})$ & 0.9 \\
\hline $\mathrm{Fe}_{\mathrm{d}}\left(\mathrm{g} \mathrm{kg}^{-1}\right)$ & 6.4 \\
\hline $\mathrm{Fe}_{\mathrm{ox}}\left(\mathrm{g} \mathrm{kg}^{-1}\right)$ & 1.0 \\
\hline \multicolumn{2}{|c|}{ 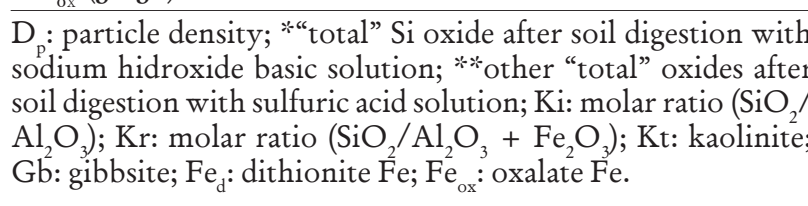 } \\
\hline
\end{tabular}

Table 2 - Chemical attributes of Inceptisol samples amended with vinasse.

\begin{tabular}{|c|c|c|c|c|c|c|c|c|c|c|c|c|c|c|c|c|}
\hline Treat. & PZSE & $\mathrm{pH} \mathrm{H} \mathrm{H}_{2} \mathrm{O}$ & $\mathrm{pH} \mathrm{KCl}$ & $\Delta \mathrm{pH}^{(1)}$ & $\mathrm{P}^{(2)}$ & $\mathrm{K}$ & $\mathrm{Ca}$ & $\mathrm{Mg}$ & $\mathrm{Al}$ & $\mathrm{H}+\mathrm{Al}$ & SB & $\mathrm{t}$ & CEC & $\mathrm{V}$ & $\mathrm{m}$ & $\mathrm{OM}$ \\
\hline & & & & & \multicolumn{9}{|c|}{$\mathrm{mg} \mathrm{dm}{ }^{-3}$} & - & 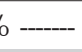 & $\mathrm{g} \mathrm{kg}^{-1}$ \\
\hline TO & 5.5 & 6.0 & 4.9 & -1.1 & 2.1 & 28.0 & 2.0 & 0.6 & 0.3 & 3.6 & 2.7 & 3.0 & 6.3 & 42.8 & 10.0 & 24.0 \\
\hline $\mathrm{T} 1$ & 5.5 & 5.9 & 5.0 & -0.9 & 3.4 & 50.0 & 1.8 & 0.5 & 0.3 & 4.0 & 2.4 & 2.7 & 6.4 & 37.5 & 11.1 & 27.0 \\
\hline $\mathrm{T} 2$ & 5.5 & 5.7 & 5.0 & -0.7 & 4.3 & 70.0 & 2.5 & 0.5 & 0.3 & 4.0 & 3.2 & 3.5 & 7.2 & 44.4 & 8.6 & 28.0 \\
\hline T3 & 5.9 & 5.5 & 5.1 & -0.4 & 4.9 & 111.0 & 2.0 & 1.0 & 0.3 & 4.0 & 3.3 & 3.6 & 7.3 & 45.2 & 8.3 & 32.0 \\
\hline
\end{tabular}

T0: control (soil characterization without the application of vinasse); T1, T2 and T3: with saturation of the samples with diluted vinasse $20 \%, 50 \%$ and natural $(100 \%)$ vinasse, respectively, and incubated for seven days; PZSE: point of zero salt effect - graphically obtained by the point of intersection of curves of potentiometric titration of two solutions $(5$ and $50 \mathrm{mM} \mathrm{NaCl}) ;{ }^{(1)} \Delta \mathrm{pH}=\mathrm{pH}(\mathrm{KCl}$ $-\mathrm{H}_{2} \mathrm{O}$ ); ${ }^{(2)}$ Phosphorus (extractor Mehlich-1); SB: sum of the exchangeable base; $t$ : effective cation exchange capacity; CEC: potential cation exchange capacity; V: base saturation; m: aluminum saturation; OM: organic matter. 
$\mathrm{Pb}\left(\mathrm{NO}_{3}\right)_{2}$ in a $5 \mathrm{mmol} \mathrm{L}^{-1} \mathrm{Ca}\left(\mathrm{NO}_{3}\right)_{2}$, solution, the $\mathrm{pH}$ adjusted to $5.5( \pm 0.2)$ with a saturated solution of $\mathrm{Ca}(\mathrm{OH})_{2}$ $\left(11.12 \mathrm{mmol} \mathrm{L}^{-1}\right)$. Samples were shaken at room temperature $\left(22^{\circ} \mathrm{C} \pm 2\right)$ and normal pressure conditions, for $72 \mathrm{~h}$, alternating $12 \mathrm{~h}$ shaking and $12 \mathrm{~h}$ repose. After that, the samples were centrifuged for $10 \mathrm{~min}$ at $500 \mathrm{x} \mathrm{g}$. The supernatant solution was collected and immediately analyzed for $\mathrm{Pb}$. Each bottle was weighed to determine the volume of entrained solution. Sorbed $\mathrm{Pb}$ was calculated by the difference between the initial and final $\mathrm{Pb}$ concentrations and was expressed in millimols per kilogram:

Sorbed $\mathrm{Pb}=\left(\mathrm{Pb}_{\text {initial }}-\mathrm{Pb}_{\text {final }}\right) \cdot \mathrm{V} / \mathrm{kg}$ soil

where $\mathrm{Pb}_{\text {initial }}$ and $\mathrm{P}_{\text {final }}$ are the initial and final solutionphase $\mathrm{Pb}$ concentrations $\left(\mathrm{mmol} \mathrm{L}^{-1}\right)$, and $\mathrm{V}$ is the solution volume (L).

To measure $\mathrm{Pb}$ desorption, $25 \mathrm{~mL}$ of a solution of a $5 \mathrm{mmol} \mathrm{L}{ }^{-1} \mathrm{Ca}\left(\mathrm{NO}_{3}\right)_{2}$, solution $(\mathrm{pH} 5.5 \pm 0.2)$ were added to the remaining soil residue. Bottles were shaken under the same conditions as previously described, centrifuged, and the supernatant was analyzed for the $\mathrm{Pb}$ concentration. The desorbed $\mathrm{Pb}$ was:

Desorbed $\mathrm{Pb}=\left[\mathrm{Pb}_{\mathrm{d}}\left(\mathrm{V}_{\mathrm{d}}+\mathrm{V}_{\text {entr }}\right)-\mathrm{Pb}_{\text {final }} \cdot \mathrm{V}_{\text {entr }}\right] / \mathrm{kg}$ soil

where $\mathrm{Pb}_{\mathrm{d}}$ is the $\mathrm{Pb}$ concentration in the desorption supernatant, $\mathrm{V}_{\mathrm{d}}$ is the volume of $\mathrm{Ca}\left(\mathrm{NO}_{3}\right)_{2}$ solution added during desorption step, and $\mathrm{V}_{\text {entr }}$ is the volume of solution entrained into the bottles after the sorption step. The residual $\mathrm{Pb}$ was calculated by the difference between the sorbed and desorbed $\mathrm{Pb}$.

Sorption isotherms were obtained in order to describe the $\mathrm{Pb}$ sorption from the samples and data was adjusted according to Langmuir's model:

Sorbed $\mathrm{Pb}=\mathrm{K} \cdot \mathrm{Pb}_{\text {final }} \cdot \mathrm{Pb}_{\text {max }} / 1+\mathrm{K} \cdot \mathrm{Pb}_{\text {final }}$

where $\mathrm{K}$ is the Langmuir's constant (related to sorption binding energy) and $\mathrm{Pb}_{\max }$ is the maximum sorption capacity of $\mathrm{Pb}\left(\mathrm{mmol} \mathrm{kg}^{-1}\right)$. K and $\mathrm{Pb}_{\text {max }}$ were obtained from the linear form of Langmuir's model. These data were submitted to $\mathrm{F}$ Test and the averages were compared by Scott-Knott Test $(p<0.05)$.

\section{$\mathrm{Pb}$ leaching experiment}

Soil columns were packed in PVC tubes with $12-\mathrm{cm}$ height and 4-cm internal diameter, with $200 \mathrm{~g}$ of aggregates $(1-2 \mathrm{~mm})$ with an average density of $1.00 \pm 0.04 \mathrm{~g}$ $\mathrm{cm}^{-3}$ and total porosity of $0.59 \pm 0.02 \mathrm{~cm}^{3} \mathrm{~cm}^{-3}$. The bottom of the columns was perforated at the center $(7-\mathrm{mm}$ diameter) and had an acrylic screen (1 $\mathrm{mm}$ mesh) to prevent the presence of particles in the leachate. The vinasse's doses applied to the soil columns corresponded to 0 (control), 150 and $300 \mathrm{~m}^{3} \mathrm{ha}^{-1}$. The highest dose was enough to reach the field capacity of the soil in the columns $\left(0.30 \mathrm{~cm}^{3} \mathrm{~cm}^{-3}\right.$ or $1 / 2$ pore volume). Distilled water was added to the $150 \mathrm{~m}^{3} \mathrm{ha}^{-1}$ dose treatment so that the field capacity could also be reached. The control samples' field capacity was reached by only adding distilled water. The soil columns were incubated during seven days at room temperature $\left(22^{\circ} \mathrm{C} \pm 2\right)$ and normal pressure conditions. The field capacity was kept constant by replacing the evaporated water with distilled water on a daily-basis. The evaporation from soil columns ranged from 1.5 to $2 \mathrm{~mm}_{\text {day }}{ }^{-1}$.

After the incubation period, $5 \mathrm{~mL}$ of a $\mathrm{Pb}\left(\mathrm{NO}_{3}\right)_{2}$ solution $\left(100 \mathrm{mmol} \mathrm{L}^{-1} \mathrm{~Pb}\right)$ were applied on the top surface of the columns. The amount of $\mathrm{Pb}$ applied was equivalent to $2.5 \mathrm{mmol} \mathrm{kg}{ }^{-1}$ of soil. In the next day, 20 $\mathrm{mL}$ ( 0.16 pore volume) of distilled water (simulating a $10 \mathrm{~mm}$ irrigation or rainfall) were applied. Leachate was collected to determine the $\mathrm{Pb}$ as described in the batch sorption experiment. This procedure was repeated five times, every other day, totaling six leachings (one pore volume) and a total irrigation or rainfall of $60 \mathrm{~mm}$.

\section{Results and Discussion}

\section{Batch sorption experiment}

In all initial $\mathrm{Pb}$ solutions, there was an increase in the sorbed and residual $\mathrm{Pb}$, in the samples treated with vinasse, mainly in the initial $\mathrm{Pb}$ solutions of $0.25,0.50$ and $0.75 \mathrm{mmol} \mathrm{L}^{-1}$ (Figure 1).

The presence of colloidal organic compounds of vinasse accounted for increased $\mathrm{Pb}$ sorption on the solid phase. Fructose, glucose, sucrose, glycerol, galactose, acetate, oxalate, citrate, among others, are found in sugarcane vinasse (Doelsch et al., 2009). A small increase in organic matter content was observed in the samples (Table 2). The higher $\mathrm{Pb}$ sorption in the samples that were treated with vinasse can also be associated with the formation of organometallic complexes on the soil mineral surfaces (Schwab et al., 2005). These interactions can be influenced by the affinity between the organic compounds and the components from the inorganic fraction of the soil, especially the oxides. This would enable the formation of "metal-organic oxide-ligand" ternary complexes, increasing the $\mathrm{Pb}$ retention capacity in soils (McBride, 1994). In this context, it was found a greater sorption capacity of the organic compounds from vinasse on the $\mathrm{Fe}$ oxides synthetics (goethite and hematite), which was approximately fivefold the sorption on the surface of kaolinite (Benke et al. (1999).

In comparison to other metals, $\mathrm{Pb}$ tends to be more sorbed in the soils due to its lower electronegativity as related to oxygen, which favors covalent bonds, and its high capacity to hydrolyze (McBride, 1994; Pierangeli et al., 2001c; Pierangeli et al., 2004). Additionally, $\mathrm{Pb}$ sorption in the soil is related to the solid phase composition; the organic matter is considered the most important soil component that is responsible for the retention capacity of this metal in the soil (Sipos et al., 2005). In soils with variable charge, $\mathrm{Fe}$ oxides also have great influence on the sorptive behavior of $\mathrm{Pb}$ (Pierangeli et al., 2001b), especially at high $\mathrm{pH}$ contitions (Pierangeli et al., 2001a).

Madrid and Díaz-Barrientos (1998), Hooda and Alloway (1998), Schwab et al. (2005) and Wong et al. (2007) have demonstrated the role of organic compounds 

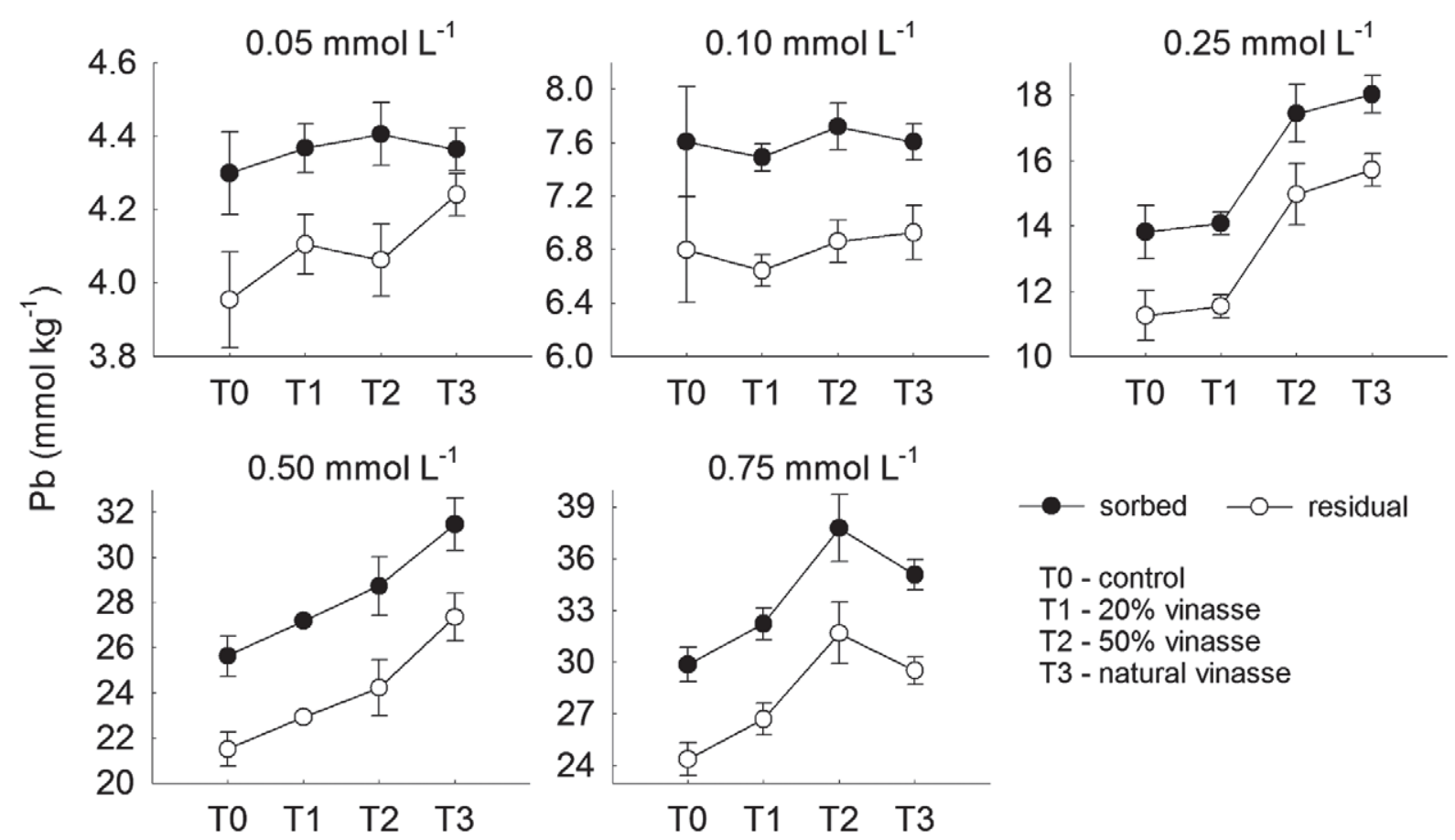

Figure 1 - Sorbed and residual $\mathrm{Pb}$ in Inceptisol samples amended with diluted vinasse $20 \%, 50 \%$, and natural (100\%) vinasse, which were kept reacting in $\mathrm{Pb}$ solutions $\left(0.05 ; 0.10 ; 0.25 ; 0.50\right.$ and $\left.0.75 \mathrm{mmol} \mathrm{L}^{-1}\right)$. Error bars indicate the average standard deviation $(\mathrm{n}=3)$.

present in residues from different origins on the sorptive behavior of metals in soils. The metal sorption in organic compounds is related to the sharing of electrons between metal surface and the organic functional groups. A stable bonding between the metal and the organic compound can take to either the occurrence of organometallic complexes in the solid phase or in the soil solution (Canellas et al., 1999). Besides, the oxidation of oxygen functional groups that form the bonds can determine the metal release in the soil solution. The influence of vinasse was also observed on copper adsorption in calcareous soils (Rodriguez-Rubio et al., 2003).

The addition of vinasse to the soil can contribute to the increase the cation exchange capacity (Leal et al., 1983; Sengik et al., 1988; Silva et al., 2007), which can also increase the $\mathrm{Pb}$ sorption. However, the present study did not show significant vinasse effect on the cation exchange capacity and the point of zero salt effect (PZSE) that could lead to an increase in the negative charge (Table 2). In fact, a slight decrease in the water-pH and an increase in $\mathrm{KCl}-\mathrm{pH}$ were observed in the samples that were treated with vinasse, indicating a reduction of the negative charges (Tan, 1993). Initially, because of its low $\mathrm{pH}$, the addition of vinasse led to a decrease of $\mathrm{pH}$ in the soil solution. Then, the soil $\mathrm{pH}$ increased, because of the reductive environment (which consumes $\mathrm{H}^{+}$ions) that was imposed by the presence of organic compounds in vinasse, which presents high biochemical demand of oxygen (Leal et al., 1983; Mattiazzo and Glória, 1987; Doelsch et al., 2009). This, indirectly, can lead to an increase in the $\mathrm{Pb}$ sorption due to a higher CEC of the colloids with variable charges.
$\mathrm{Pb}$ sorption by the soil samples was well described by the sorption isotherms adjusted to Langmuir's model (Figure 2A). Isotherms had an L-type form, which were first characterized by a high affinity between the metal and the soil and reached the highest degree where the saturation of the sorption sites occurred (Pierangeli et al., 2007; Wong et al., 2007). Samples treated with 50\%diluted vinasse and natural vinasse had an increase in the $\mathrm{Pb}_{\text {max }}$ (Figure 2B), as compared to the control-TO and $20 \%$ vinasse-T1. An increase in the sorption binding energy was also observed when the samples were treated with natural vinasse.

\section{$\mathrm{Pb}$ leaching experiment}

The amount of $\mathrm{Pb}$ added to the columns $(2.5 \mathrm{mmol}$ $\mathrm{kg}^{-1}$ of soil) was bellow the maximum sorption capacity $\left(\mathrm{Pb}_{\max }\right)$ (Figure $\left.2 \mathrm{~A}\right)$. Nevertheless, after the experiment, a small fraction of non-adsorbed $\mathrm{Pb}(<0.5 \%$ of total applied) was influenced by the presence of vinasse in the columns (Figure 3). Less $\mathrm{Pb}$ was released from control samples, as compared to those with vinasse (150 and $300 \mathrm{~m}^{3} \mathrm{ha}^{-1}$ ) (Figure 4). The highest dose of vinasse account for higher amount of accumulated $\mathrm{Pb}$ in the leachate. This is related to the binding between organic compounds of vinasse and $\mathrm{Pb}$ in the soil solution, which enhanced mobility through the soil columns, under the successive leaching. Similar results were found for soil columns under the influence of EDTA in an Oxisol (Gabos et al., 2009), and citrate and oxalate in a Spodosol (Freitas et al., 2009), which shows the interaction of chelate with $\mathrm{Pb}$. Similarly, leaching of $\mathrm{Zn}$ and $\mathrm{Cu}$ from homogeneous soil 
- $\mathrm{TO}$ - Control Sorbed $\mathrm{Pb}=\left(536.87 \mathrm{~Pb}_{\text {final }}\right) /\left(1+16.63 \mathrm{~Pb}_{\text {fnal }}\right) \quad \mathrm{R}^{2}=0.93$

- $\mathrm{T} 1-20 \%$ vinasse Sorbed $\mathrm{Pb}=\left(538.14 \mathrm{~Pb}_{\text {final }}\right) /\left(1+15.25 \mathrm{~Pb}_{\text {final }}\right) \quad \mathrm{R}^{2}=0.93$

- $\mathrm{T} 2-50 \%$ vinasse Sorbed $\mathrm{Pb}=\left(696.36 \mathrm{~Pb}_{\text {final }}\right) /\left(1+17.07 \mathrm{~Pb}_{\text {final }}\right) \quad \mathrm{R}^{2}=0.95$

- $\mathrm{T} 3$ - natural vinasse Sorbed $\mathrm{Pb}=\left(802.58 \mathrm{~Pb}_{\text {final }}\right) /\left(1+20.57 \mathrm{~Pb}_{\text {final }}\right) \quad \mathrm{R}^{2}=0.97$

- Langmuir's model
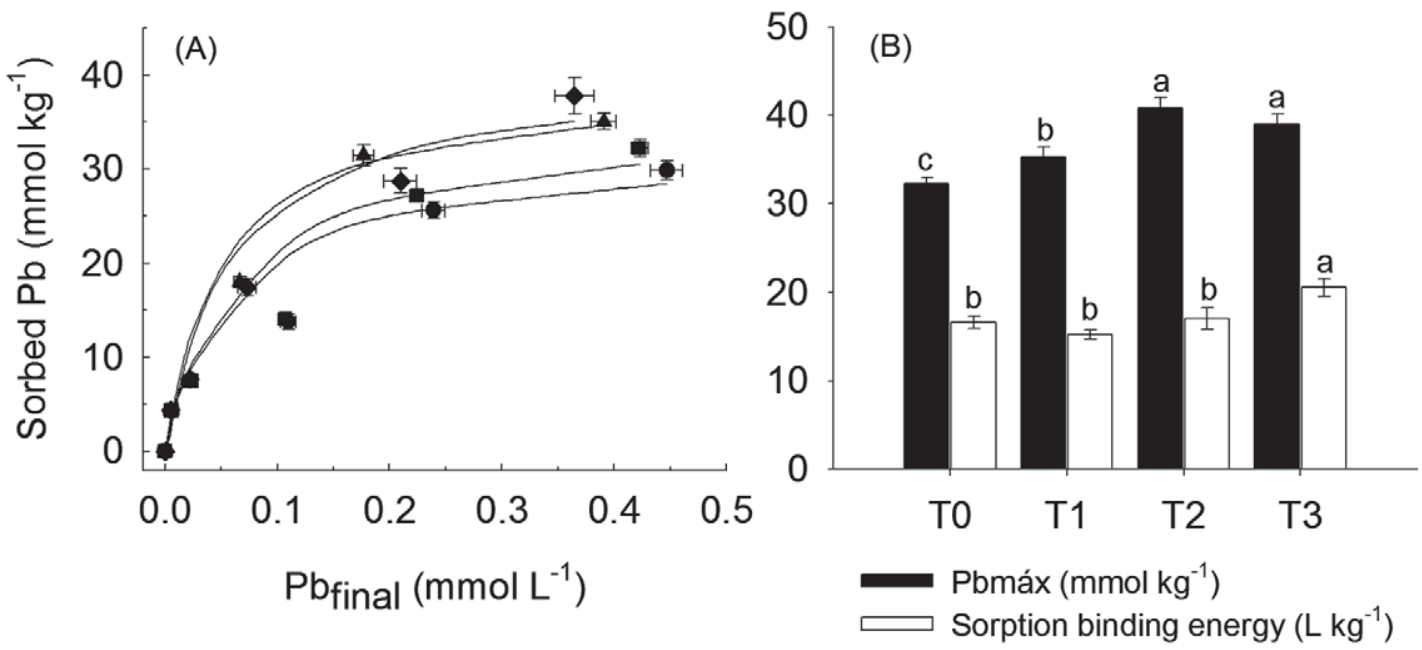

Figure 2 - Pb sorption isotherms adjusted to Langmuir's model of Inceptisol samples amended with vinasse (A). Bidirectional error bars indicate the average standard deviation $(\mathrm{n}=3) . \mathrm{Pb}_{\text {máx }}$ and sorption binding energy $(\mathrm{B})$ estimated by linearized Lagmuir model. Averages followed by the same small letter do not differ (Scott-Knott Test, $p>0.05$ ).

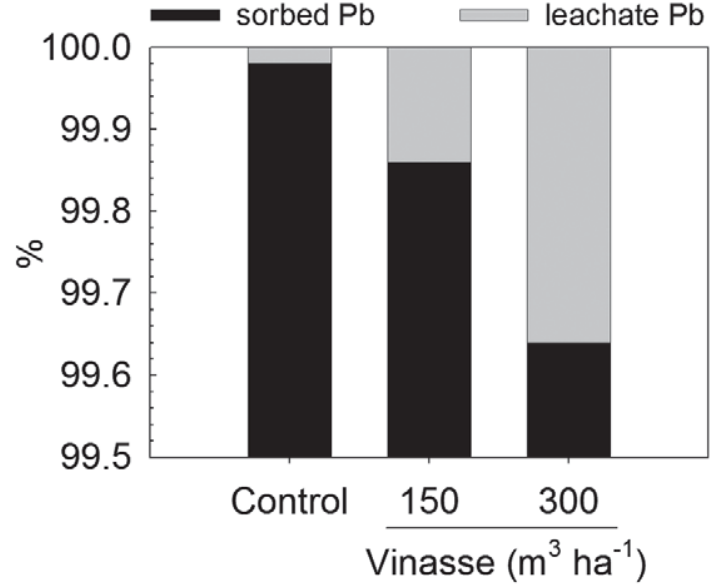

Figure 3 - Relative amounts of sorbed and leachate $\mathrm{Pb}$ after all leachings from columns containing Inceptisol samples under the influence of vinasse.

columns (the same size used in this work) was enhanced when soils were treated with two wastewaters from an agricultural industry (olive-mill wastewater and concentrated sugarbeet vinasse) (Madrid and Díaz-Barrientos, 1998).

Comparison of the results between batch and leaching experiments

The increase in the $\mathrm{Pb}$ sorption in the samples treated with vinasse (Figures 1 and 2), if interpreted based on the results of the batch sorption experiment, may be due to the formation of organometallic com-

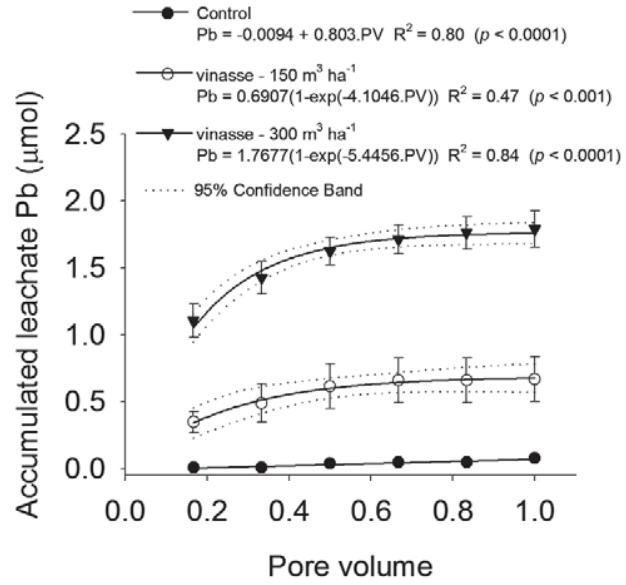

Figure 4 - Accumulated leachate $\mathrm{Pb}$ after successive leachings from columns containing sample of Inceptisol samples under the influence of vinasse. Error bars indicate the average standard deviation $(\mathrm{n}=3)$.

pounds which were adsorbed on the soil mineral particles (Schwab et al., 2005). When analyzing the $\mathrm{Pb}$ in the leachate of soil columns (Figures 3 and 4), it was observed that a small fraction of the metal that was present in the soil solution moved because of the presence of vinasse, due to the formation of the soluble organometallic complexes in the soil solution. Dispersion of particles occurring in the batch sorption procedures, increased the surface for reaction; this is caused by the constant agitation and desorbed species can be resorbed by the matrix. Thus, the results of the batch sorption experiment may overestimate the real sorption capacity 
in natural conditions. In soil columns, since they are open systems, the unbalanced conditions are more closely related to natural conditions, where the desorbed species are removed and the reverse reactions are much less probable to occur.

Based on the results of the $\mathrm{Pb}$ leaching experiment, which is more closely related to the field conditions, special attention must be given to the agricultural areas that receive large quantities of vinasse and are also exposed to contamination with $\mathrm{Pb}$; for example: through the use of phosphate fertilizers (Campos et al., 2005) with sewage sludge or biosolids of urban and industrial origins (Silveira et al., 2003; Borges and Coutinho, 2004; Oliveira et al., 2005; Silva et al., 2006; Torri and Lavado, 2008; Galdos et al., 2009). This can happen where sewage sludge is used as a source of $\mathrm{N}$ and vinasse is used as a source of $\mathrm{K}$ as may occurs in sugarcane crops (Franco et al., 2008). In this case, the sewage sludge may contain a significant amount of $\mathrm{Pb}$ and accounts for soil contamination (Camilotti et al., 2007).

According to the quantity and frequency of the vinasse amended to the soil, it may reach the groundwater (Lyra et al., 2003), carrying along sorbed $\mathrm{Pb}$, thus affecting the ground water quality. The $\mathrm{Pb}$ may be passively co-transported by organic matter which also enhances its mobility in soils by the formation of highly mobile organic colloids (Lang et al., 2005).

\section{Conclusions}

At equilibrium conditions, the applied vinasse increased the $\mathrm{Pb}$ 's maximum sorption capacity and binding energy in the soil. However, at non-equilibrium conditions, the vinasse enhanced $\mathrm{Pb}$ leaching. The results of the batch sorption experiment may overestimate the real sorption capacity in natural conditions.

\section{Acknowledgements}

To Fapemig and CNPq for the financial support to this research.

\section{References}

Benke, M.B.; Mermut, A.R.; Shariatmadari, H. 1999. Retention of dissolved organic carbon from vinasse by a tropical soil, kaolinite, and Fe-oxides. Geoderma 91: 47-63.

Borges, M.R.; Coutinho, E.L.M. 2004. Heavy metals in soil after sewage sludge application. II. Availability. Revista Brasileira de Ciência do Solo 28: 557-568. (in Portuguese, with abstract in English).

Campos, M.L.; Silva, F.N.; Furtini Neto, A.E.; Guilherme, L.R.G.; Marques, J.J.; Antunes, A.S. 2005. Determination of cadmium, copper, chromium, nickel, $\mathrm{Pb}$ and zinc in rock phosphates. Pesquisa Agropecuária Brasileira 40: 361-367. (in Portuguese, with abstract in English).

Camargo, O.A.; Valadares, J.M.A.S.; Geraldi, R.N. 1983. Physical and Chemical Characteristics of Soil Amended with Vinasse for Many Years. Instituto Agronômico, Campinas, SP, Brazil. (in Portuguese).
Camilotti, F.; Marques, M.O.; Andrioli, I.; Silva, A.R.; Tasso Junior, L.C.; Nobile, F.O. 2007. Heavy metals accumulation in sugarcane after application in sewage sludge and vinasse. Engenharia Agrícola 27: 284-293. (in Portuguese, with abstract in English).

Canellas, L.P.; Nelson, G.A.S.; Amaral Sobrinho, M.B.; Moraes, A.A.; Rumjamek, V.M. 1999. $\mathrm{Cu}^{2+}$ and $\mathrm{Cd}^{2+}$ adsorption by humic acids extracted from urban organic residues. Ciência Rural 29: 21-26. (in Portuguese, with abstract in English).

Doelsch, E.; Masion, A.; Cazevieille, P.; Condom, N. 2009. Spectroscopic characterization of organic matter of a soil and vinasse mixture during aerobic or anaerobic incubation. Waste Management 29: 1929-1935.

Empresa Brasileira de Pesquisa Agropecuária [EMBRAPA]. 1997. Methods of soil analysis. 2ed. Centro Nacional de Pesquisa de Solos, Rio de Janeiro, RJ, Brasil. (in Portuguese).

Empresa Brasileira de Pesquisa Agropecuária [EMBRAPA]. 2006. Brazilian System of Soil Classification. 2ed. Centro Nacional de Pesquisa de Solos, Rio de Janeiro, RJ, Brazil. (in Portuguese).

Franco, A.; Marques, M.O.; Melo, W.J. 2008. Sugarcane grown in an Oxisol amended with sewage sludge and vinasse: nitrogen contents in soil and plant. Scientia Agricola 65: 408-414.

Freire, W.J.; Cortez, L.A.B. 2000. Sugarcane Vinasse. Agropecuária, Guaíba, RS, Brazil. (in Portuguese).

Freitas, E.V.S.; Nascimento, C.W.A.; Biondi, C.M.; Silva, J.P.S.; Souza, A.P. 2009. Pb desorption and leaching in a Spodosol amended with chelant agents. Revista Brasileira de Ciência do Solo 33: 517-525. (in Portuguese, with abstract in English).

Gabos, M.B.; Abreu, C.A.; Coscione, A.R. 2009. EDTA assisted phytorremediation of a $\mathrm{Pb}$ contaminated soil: metal leaching and uptake by lack beans. Scientia Agricola 66: 506-514.

Galdos, M.V.; De Maria, I.C.; Carmago, O.A.; Dechen, C.F. 2009. Sewage sludge application on cultivated soils: effect on runoff and trace metal load. Scientia Agricola 66: 368-376.

Günkel, G.; Kosmol, J.; Sobral, M.; Rohn, H.; Montenegro, S.; Aureliano, J. 2007. Sugar cane industry as a source of water pollution: case study on the situation in Ipojuca River, Pernambuco, Brazil. Water Air Soil Pollution 180: 261-269.

Hooda, P.S.; Alloway, B.J. 1998. Cadmium and lead sorption behaviour of selected English and Indian soils. Geoderma 84: 121-134.

Instituto Brasileiro de Geografia e Estatística [IBGE]. 2009. Available at: http://www. ibge.gov.br [Accessed Apr. 01, 2009]. (in Portuguese).

Jalali, M.; Khanboluki, G. 2007. Leaching of zinc, cadmium, and lead in a sandy soil due to application of poultry litter. Soil \& Sediment Contamination 16: 47-60.

Kabata-Pendias, A.; Pendias, H. 2000. Trace elements in soil and plants. 2 ed. CRC Press, Boca Raton, FL, USA.

Lang, F.; Egger, H.; Kaupenjohann, M. 2005. Size and shape of lead-organic associations. Colloids and Surfaces 265: 95-103.

Leal, J.R.; Amaral Sobrinho, N.M.B.; Velloso, A.C.X.; Rossiello, R.O.P. 1983. Redox potential and $\mathrm{pH}$ : variations in a soil treated with stillage. Revista Brasileira de Ciência do Solo 7: 257-261. (in Portuguese, with abstract in English).

Lyra, M.R.C.C.; Rolim, M.M.; Silva, J.A.A. 2003. Toposequence of soils fertigated with stillage: contribution towards the quality of ground water table. Revista Brasileira de Engenharia Agrícola e Ambiental 7: 525-532. (in Portuguese, with abstract in English).

Madrid, L.; Díaz-Barrientos, E. 1998. Release of metals from homogeneous soil columns by wastewater from an agricultural industry. Environmental Pollution 101: 43-48.

Martinelli, L.A.; Filloso, S. 2008. Expansion of sugarcane ethanol production in Brazil: environmental and social challenges. Ecological Applications 18: 885-898.

Mattiazzo, M.E.; Glória, N.A. 1987. Effect of vinasse on soil acidity. Water Science Technology 19: 1293-1296.

McBride, M.B. 1994. Environmental Chemistry of Soils. Oxford University Press, New York, NY, USA. 
Neves, M.C.P.; Lima, L.T.; Dobereiner, J. 1983. Effect of land disposal of stillage on soil microorganisms. Revista Brasileira de Ciência do Solo 7: 131-136. (in Portuguese, with abstract in English).

Oliveira, K.W.; Melo, W.J.; Pereira, G.T.; Melo, V.P.; Melo, G.M.P. 2005. Heavy metals in Oxisols amended with biosolids and cropped with mayze in a long-term experiment. Scientia Agrícola 62: 381-388.

Pierangeli, M.A.P.; Guilherme, L.R.G.; Curi, N.; Anderson, S.J.; Lima, J.M. 2004. Cadmium, copper, and lead adsorption and desorption in Oxisol samples pre-treated with phosphorus. Revista Brasileira de Ciência do Solo 28: 377-384. (in Portuguese, with abstract in English).

Pierangeli, M.A.P.; Guilherme, L.R.G.; Curi, N.; Costa, E.T.S.; Lima, J.M.; Marques, J.J.G.S.M.; Figueiredo, L.F.P. 2007. Individual and competitive sorption of heavy metals in Oxisols with contrasting mineralogy. Revista Brasileira de Ciência do Solo 31: 819-826. (in Portuguese, with abstract in English).

Pierangeli, M.A.P.; Guilherme, L.R.G.; Curi, N.; Silva, M.L.N.; Oliveira, L.R.; Lima, J.M. 2001a. Lead adsorption-desorption in Brazilian Oxisols as a function of $\mathrm{pH}$. Revista Brasileira de Ciência do Solo 25: 269-277. (in Portuguese, with abstract in English).

Pierangeli, M.A.P.; Guilherme, L.R.G.; Curi, N.; Silva, M.L.N.; Oliveira, L.R.; Lima, J.M. 2001b. Total lead content and maximum adsorption capacity in Brazilian Oxisols. Revista Brasileira de Ciência do Solo 25: 279-288. (in Portuguese, with abstract in English).

Pierangeli, M.A.P.; Guilherme, L.R.G.; Oliveira, L.R.; Curi, N.; Silva, M.L.N. 2001c. Effect of ionic strength of the equilibrium solution upon lead adsorption/desorption in Brazilian Oxisols. Pesquisa Agropecuária Brasileira 36: 1077-1084. (in Portuguese, with abstract in English).

Rodriguez-Rubio, P.; Morillo, E.; Madrid, L.; Undabeytia, T.; Maqueda, C. 2003. Retention of copper by a calcareous soil and its textural fractions: influence of amendment with two agroindustrial residues. European Journal of Soil Science 54: 401-409.
Schwab, A.P.; Yinghong, H.; Banks, M.K. 2005. The influence of organic ligands on the retention of lead in soil. Chemosphere 61: 856-866.

Sengik, E.; Ribeiro, A.C.; Condé, A.R. 1988. Effects of stillage on properties of two soil samples of Viçosa, state of Minas Gerais, Brazil. Revista Brasileira de Ciência do Solo 12: 11-15. (in Portuguese, with abstract in English).

Sharma, P.; Dubey, R.S. 2005. Lead toxicity in plants. Brazilian Journal Plant Physiology 17: 35-52.

Silva, C.A.; Rangel, O.J.P.; Dynia, J.F.; Bettiol, W.; Manzatto, C.V. 2006. Heavy metals availability for corn cultivated in a Latosol successively amended with sewage sludge. Revista Brasileira de Ciência do Solo 30: 53-364. (in Portuguese, with abstract in English).

Silva, M.A.S.; Griebeler, N.P.; Borges, L.C. 2007. Use of stillage and its impact on soil properties and ground water. Revista Brasileira de Engenharia Agrícola e Ambiental 11: 108-114. (in Portuguese, with abstract in English).

Silveira, M.L.A.; Alleoni, L.R.F.; Guilherme, L.R.G. 2003. Biosolids and heavy metals in soils. Scientia Agricola 60: 793-806.

Sipos, P.; Németh, T.; Mohai, I.; Dódony, I. 2005. Effect of soil composition on adsorption of lead as reflected by a study on a natural forest soil profile. Geoderma 124: 363-374.

Tan, K.H. 1993. Principles of Soil Chemistry. 2ed. Marcel Dekker, New York, NY, USA.

Torri, S.I.; Lavado, R.S. 2008. Dynamics of $\mathrm{Cd}, \mathrm{Cu}$ and $\mathrm{Pb}$ added to soil through different kinds of sewage sludge. Waste Management 28: 821-832.

Vega, F.A.; Covelo, E.F.; Vázquez, J.J.; Andrade, L. 2007. Influence of mineral and organic components on cooper, lead, and zinc sorption by acid soils. Journal of Environmental Science and Health Part A 42: 2167-2173.

Wong, J.W.C.; Li, K.L.; Zhou, L.X.; Selvam, A. 2007. The sorption of $\mathrm{Cd}$ and $\mathrm{Zn}$ by different soils in the presence of dissolved organic matter from sludge. Geoderma 137: 310-317.

Received May 08, 2009

Accepted March 31, 2010 